\title{
Monitoring hemostasis parameters in left ventricular assist device recipients - a preliminary report
}

\author{
Bartosz Hudzik ${ }^{1}$, Jacek Kaczmarski², Jerzy Pacholewicz ${ }^{3}$, Michał Zakliczyński ${ }^{3}$, Mariusz Gąsior ${ }^{1}$, \\ Marian Zembala ${ }^{3}$ \\ ${ }_{1}^{1}{ }^{\text {rd }}$ Department of Cardiology, Silesian Centre for Heart Disease, SMDZ in Zabrze, Medical University of Silesia in Katowice, \\ Poland \\ ${ }^{2}$ Hemostasis Laboratory, Silesian Centre for Heart Disease, Zabrze, Poland \\ ${ }^{3}$ Department of Cardiac, Vascular and Endovascular Surgery and Transplantology, Silesian Centre for Heart Disease, \\ SMDZ in Zabrze, Medical University of Silesia in Katowice, Poland \\ Kardiochirurgia i Torakochirurgia Polska 2016; 13 (3): 224-228
}

\begin{abstract}
Introduction: Mechanical circulatory support (MCS) therapy is associated with the improvement of long-term prognosis in patients with end-stage heart failure. For years it has been used as a bridge to transplant. However, more recently it is even being used as a destination therapy. Recently, clinicians have identified common MCS therapy-associated complications: pump thrombosis, bleeding, and hemolysis. These complications are very challenging with regard to both diagnosis and management.

Aim: To determine time-dependant changes of selected hemostasis/coagulation parameters in patients with end-stage heart failure treated with MCS and antithrombotic therapy.

Material and methods: Sixteen patients with end-stage heart failure on left ventricular assist device (LVAD) were followed for 6 weeks (six blood samples for each patient). Every week an extended hemostasis panel was assessed, including activated partial thromboplastin time, prothrombin time, international normalized ratio, von Willebrand factor (VWF) activity, factor VIII activity, fibrinogen level, D-dimer, platelet response to arachidonic acid (ASPI test) and adenosine diphosphate (ADP test), thrombin receptor activating peptide-6 (TRAP test) and collagen (COL test).

Results: The study population comprised 16 men. The median time from LVAD implantation was 120 days (100-150 days). During the study period the D-dimer and fibrinogen concentrations were elevated but remained similar throughout all six measurements. Meanwhile factor VIII and VWF activities were elevated in the first two measurements and then subsequently declined. Inhibition of platelet aggregation was greater early after LVAD implantation. During subsequent weeks the inhibition of platelet aggregation was less pronounced. No patient developed any bleeding or thrombo-embolic event during the study period.
\end{abstract}

\section{Streszczenie}

Wstęp: Mechaniczne wspomaganie układu krążenia (MCS) poprawia rokowanie chorych ze schyłkową niewydolnością serca. Przez lata metodę tę uznawano za leczenie pomostowe do transplantacji serca. Od niedawna stosuje się ją jako leczenie docelowe. Do częstych powikłań MCS należą: incydenty zakrzepowe (w tym zakrzepica urządzenia), incydenty krwotoczne oraz hemoliza. Powikłania te stanowią złożony problem kliniczny zarówno pod względem diagnostyki, jak i leczenia.

Cel: Ocena zmian w czasie wybranych parametrów układu krzepnięcia u chorych ze schyłkową niewydolnością serca leczonych za pomocą MCS i terapii przeciwzakrzepowej.

Materiat i metody: Przez 6 tygodni obserwowano 16 pacjentów ze schyłkową niewydolnością serca (sześć pobrań krwi dla każdego pacjenta). Co tydzień oceniano rozszerzony panel badań układu krzepnięcia, w tym czas częściowej tromboplastyny po aktywacji, czas protrombinowy, międzynarodowy współczynnik znormalizowany, aktywność czynnika von Willebranda (vWF), aktywność czynnika VIII, stężenie fibrynogenu, D-dimeru, czynność płytek pod wpływem kwasu arachidonowego (ASPI test) i dwufosforanu adenozyny (ADP test), aktywującego receptora trombinowego peptydu 6 (TRAP test) i kolagenu (COL test).

Wyniki: W badaniu wzięło udział 16 mężczyzn. Mediana czasu od momentu wszczepienia urządzenia wspomagającego pracę lewej komory serca (LVAD) wynosiła 120 dni (100-150 dni). Podczas badania stężenia D-dimeru oraz fibrynogenu były podwyższone we wszystkich sześciu oznaczeniach, nie stwierdzono istotnych różnic między kolejnymi oznaczeniami. Aktywność vWF i czynnika VIII były podwyższone w pierwszych dwóch oznaczeniach, w kolejnych oznaczeniach obserwowano ich zmniejszenie. Zahamowanie agregacji płytek krwi było większe zaraz po implantacji LVAD. W następnych tygodniach stwierdzono zmniejszenie stopnia zahamowania agregacji płytek krwi. Podczas trwania badania u żadnego chorego nie wystąpił incydent zakrzepowo-zatorowy ani krwotoczny.

Address for correspondence: Bartosz Hudzik MD, PhD, Third Department of Cardiology, Silesian Centre for Heart Disease, 9 Curie-Sklodowska St, 41-800 Zabrze, Poland, phone: +48 3237336 19, fax: +48 3227326 79, e-mail: bartekh@mp.pl

Received: 26.08.2016, accepted: 5.09.2016. 
Conclusions: Patients on MCS therapy demonstrate significant time-dependant changes in hemostasis parameters (both in the coagulation system and platelet aggregation).

Key words: mechanical circulatory support, left ventricular assist device, bleeding, thrombosis.

\section{Introduction}

Heart transplantation remains the first-line therapy in the management of end-stage heart failure. However, the number of transplants is estimated at less than 3,500 yearly worldwide, which is obviously inadequate to meet the demand in this rapidly growing population of heart failure patients $[1,2]$. Mechanical circulatory support (MCS) is an umbrella term describing various technologies used in both short- and long-term management of patients with either end-stage chronic heart failure (HF) or acute HF. Long-term devices are used either as a 'bridge to transplant' to support patients who are unable to wait any longer for a heart transplant, or, more recently, as 'destination therapy' for older patients suffering from end-stage heart failure and who have contraindications to heart transplantation [3, 4]. Mechanical circulatory support includes a left ventricular assist device (LVAD) or a bi-ventricular assist device (BiVAD). However, MCS therapy is not without risk. Recently, clinicians have identified common MCS therapy-associated complications: pump thrombosis, bleeding, and hemolysis [5]. These complications are very challenging with regard to both diagnosis and management.

The incidence of LVAD thrombosis is $2-13 \%$ of adult patients with a continuous-flow LVAD (axial flow 4-13\%, centrifugal flow 2\%) [6]. Therapeutic options include surgical procedures (device exchange, catheter-based thrombectomy) and medical therapy. The latter may consist of: thrombolytic therapy with recombinant tissue plasminogen activator, intensified anticoagulation treatment with unfractionated heparin, bivalirudin, intensified antiplatelet treatment with intravenous GP IIb/IIla inhibitors, or with thienopyridine-derivative P2Y12 ADP receptor inhibitor. However, there are no unified guidelines as to the antithrombotic therapy $[7,8]$. The incidence of LVAD-associated bleeding, depending on its definition, varies widely between $10 \%$ and $50 \%$, with no difference in the overall bleeding rates between axial- and pulsatile-flow devices [9]. Much of the bleeding risk is attributed to the antithrombotic regimen. However, there are reports that the observed increased risk of bleeding is higher than would be anticipated from antithrombotic therapy alone [10].

Given the coexistence of thrombo-embolic and hemorrhagic complications, monitoring of hemostasis using thromboelastometry/-graphy and platelet function analysis is recommended during MCS therapy [11]. Hemostasis assays should be used to reduce the risk of bleeding and thrombo-embolic complications during MCS therapy and antithrombotic management.
Wnioski: U pacjentów stosujących MCS wykazano znaczne zmiany w parametrach hemostazy zarówno w układzie krzepnięcia, jak i aktywności płytek krwi.

Słowa kluczowe: mechaniczne wspomaganie układu krążenia, urządzenie wspomagające pracę lewej komory serca, krwawienie, zakrzepica.

\section{Aim}

Therefore, we set out to determine time-dependant changes of selected hemostasis parameters in patients with end-stage heart failure treated with MCS and antithrombotic therapy.

\section{Material and methods}

The study conforms to the Declaration of Helsinki. The study was approved by the local Bioethics Committee, and all patients gave written consent to participate in the study.

Sixteen patients with end-stage heart failure on LVAD were followed for 6 weeks (six blood samples for each patient). Given the various effects of continuous-flow LVAD and pulsatile-flow LVAD on hemostasis [12], we included in the current study only continuous-flow LVAD recipients.

HeartMate II is an intracorporeal pump with an axial flow pattern. The pump is driven by a rotating magnetic levitated impeller and has a capacity of up to $15,000 \mathrm{rpm}$, resulting in a theoretical maximal blood flow of $8-10 \mathrm{l} / \mathrm{min}$.

HeartWare $(\mathrm{HW})$ is an intracorporeal 3rd-generation pump. It is a rotational pump with a magnetic levitating rotor (similar to a propeller). The blood flow is not axial, because inflow and outflow axes are arranged in a 90 degrees angle. Moreover, this pump runs with a lower rotation speed of 1,000 to $2,500 \mathrm{rpm}$ and generates up to $10 \mathrm{l} / \mathrm{min}$ flow.

Every week an extended hemostasis panel was assessed, including activated partial thromboplastin time (APTT), prothrombin time (PT), international normalized ratio (INR), von Willebrand factor (VWF) activity, factor VIII activity, fibrinogen level, D-dimer, platelet response to arachidonic acid (ASPI test) and adenosine diphosphate (ADP test), thrombin receptor activating peptide- 6 (TRAP test) and collagen (COL test).

Fasting venous blood samples were taken each week, and all tests were performed within one hour of blood samples' collection. Whole venous blood samples were collected from each patient and placed in 2 tubes of $4 \mathrm{ml}$ with $109 \mathrm{mmol}$ of sodium citrate (3.2\%) and in 2 tubes of $3 \mathrm{ml}$ with $>15 \mu \mathrm{g} / \mathrm{ml}$ of hirudin. Plasma was separated by centrifugation at $2000 \mathrm{~g}$ for $15 \mathrm{~min}$ at ambient temperature $\left(20-25^{\circ} \mathrm{C}\right)$. The vWF activity and D-dimers were evaluated by an immuno-turbidimetric assay, using a fully automated hemostasis analyzer (BCS XP system, Innovance Siemens Healthcare, USA). Factor VIII (\% activity of normal plasma) and coagulant fibrinogen (mg/ dl) were determined by chronometric techniques by means of fully automated hemostasis analyzers (BCS XP system, Siemens Healthcare, USA). Prothrombin time (PT, \% time of normal plasma), INR, and APTT (s) were also assessed by chronometric techniques. Platelet aggregation was tested in 
Tab. I. Baseline clinical characteristics

\begin{tabular}{ll} 
Parameter & Result \\
Age [years] & $41(24-49)$ \\
\hline Men, $n(\%)$ & $16(100)$ \\
\hline Time from LVAD implantation [days] & $60(45-120)$ \\
\hline Non-ischemic cardiomyopathy, $n(\%)$ & $9(56.2)$ \\
\hline LVAD type: & \\
- HeartWare, $n(\%)$ & $13(81.2)$ \\
- HeartMate II, $n(\%)$ & $3(18.8)$ \\
\hline Left ventricular ejection fraction (\%) & $15(10-18)$ \\
\hline Body mass index $\left[\mathrm{kg} / \mathrm{m}^{2}\right]$ & $23(19-26)$ \\
\hline
\end{tabular}

physiological calcium conditions by the Multiplate analyzer (Dynabyte, Munich, Germany), using agonists of thrombin receptor activating peptide-6 (TRAP-6), arachidonic acid (ASPI), adenosine diphosphate (ADP), and a collagen binding activity assay (COL).

The antithrombotic protocol involved the use of unfractionated heparin according to the APTT (60-80 s) starting on postoperative day (POD) 1. On POD 2 warfarin was started to achieve INR of 2.0-2.5 in continuous-flow pumps. In addition, aspirin and/or clopidogrel were used antiplatelet agents, starting from POD 2. The type and dose of antithrombotic regimen were at the discretion of the attending physician.

\section{Statistical analysis}

Continuous variables are presented as medians and interquartile ranges. Categorical variables are presented as frequencies. Friedman analysis of variance (ANOVA) test followed by Bonferroni correction and the Wilcoxon matched-pairs signed-ranks test were employed to test the difference between repeated laboratory tests during 6-week follow-up.

\section{Results}

Baseline clinical characteristic are presented in Table I. The study population comprised 16 men with a median age of 41 (interquartile range: 24-49). The median ejection fraction was $15 \%$ (10-18\%). The median time from LVAD implantation was 60 days (45-120 days). Coagulation assay results are presented in Table II. During the study period the D-dimer and fibrinogen concentrations were elevated but remained similar throughout all six measurements. Meanwhile factor VIII and VWF activities were elevated in the first two measurements and then subsequently declined. Platelet function tests are depicted in Table III. Inhibition of platelet aggregation was greater early after LVAD implantation. During subsequent weeks the inhibition of platelet aggregation was less pronounced. No patient developed any bleeding or thrombo-embolic event during the study period.

\section{Discussion}

We set out to determine time-dependant patterns in hemostasis parameters in patients with end-stage heart failure treated with LVAD. There are several key findings of our study. First, D-dimer and fibrinogen concentrations were elevated but remained similar throughout all six measurements. Second, factor VIII and VWF concentrations were elevated at the beginning of the study and then steadily declined. Third, inhibition of platelet aggregation was greater early after LVAD implantation. And finally, despite the fluctuation in hemostasis parameters, there were

Tab. II. Coagulation assay results in studied patients

\begin{tabular}{lllllll} 
Variable & $\begin{array}{l}\text { D-dimer } \\
(\mathrm{N}<0.5)[\mathrm{mg} / \mathrm{l}]\end{array}$ & $\begin{array}{l}\text { Fibrinogen } \\
(\mathrm{N}<400)[\mathrm{mg} / \mathrm{dl}]\end{array}$ & $\begin{array}{l}\text { INR } \\
(\mathrm{N} 1.2-1.8)\end{array}$ & $\begin{array}{l}\text { APTT } \\
(\mathrm{N}<38)[\mathrm{s}]\end{array}$ & $\begin{array}{l}\text { Factor VIII } \\
(\mathrm{N}<150) \text { IU/dl }\end{array}$ & $\begin{array}{l}\text { vWF } \\
(\mathrm{N}<150) \text { IU/dI }\end{array}$ \\
\hline Week 1 & $3.2(2.0-8.9)$ & $633(611-669)$ & $2.3(2.0-2.9)$ & $45(38-51)$ & $289(221-586)$ & $295(183-329)$ \\
\hline Week 2 & $4.1(3.3-7.3)$ & $698(531-813)$ & $2.5(2.1-3.1)$ & $48(40-53)$ & $201(143-367)$ & $192(141-231)$ \\
\hline Week 3 & $3.5(3.2-10.0)$ & $680(602-713)$ & $2.2(1.9-2.8)$ & $45(35-49)$ & $200(131-275)$ & $171(101-263)$ \\
\hline Week 4 & $3.9(3.6-5.9)$ & $653(527-701)$ & $2.3(2.0-2.9)$ & $46(38-49)$ & $160(120-233)$ & $188(144-247)$ \\
\hline Week 5 & $3.0(2.1-6.3)$ & $671(603-739)$ & $2.6(2.3-3.0)$ & $49(45-53)$ & $157(131-189)$ & $161(134-211)$ \\
\hline Week 6 & $2.8(2.0-5.6)$ & $641(584-714)$ & $2.5(2.2-3.3)$ & $48(41-55)$ & $162(129-197)$ & $159(130-218)$ \\
\hline$P$-value & 0.3 & 0.3 & 0.7 & 0.5 & $<0.001$ & 0.01 \\
\hline
\end{tabular}

Tab. III. Time-dependant changes in platelet function

\begin{tabular}{lllll} 
Variable & $\begin{array}{l}\text { ASPI }(\mathbf{N}>494) \\
\text { area under the curve (AUC) }[\mathrm{min}]\end{array}$ & $\begin{array}{l}\text { ADP }(\mathrm{N}>691) \\
\text { area under the curve }(\mathrm{AUC})^{*}[\mathrm{~min}]\end{array}$ & $\begin{array}{l}\text { COL test } \\
(\mathrm{N}>708)\end{array}$ & $\begin{array}{l}\text { TRAP test } \\
(\mathrm{N}>920)\end{array}$ \\
Week 1 & $371(193-1015)$ & $181(101-1430)$ & $194(166-749)$ & $320(292-1411)$ \\
\hline Week 2 & $753(530-1382)$ & $266(215-376)$ & $503(255-914)$ & $561(432-1232)$ \\
\hline Week 3 & $516(211-649)$ & $596(509-734)$ & $289(197-410)$ & $831(700-1464)$ \\
\hline Week 4 & $493(229-564)$ & $511(395-583)$ & $268(220-373)$ & $889(793-1158)$ \\
\hline Week 5 & $537(289-638)$ & $479(229-552)$ & $317(245-438)$ & $873(741-1097)$ \\
\hline Week 6 & $512(312-681)$ & $461(315-580)$ & $411(344-589)$ & $853(665-1142)$ \\
\hline$P$-value & 0.009 & 0.007 & 0.01 & 0.01 \\
\hline
\end{tabular}


no hemorrhagic or thrombo-embolic events during the study period.

Currently, long-term survival in carefully selected patients on MCS is much better than with medical therapy. However, MCS therapy is hampered by, sometimes lifethreatening, complications including bleeding and device thrombosis [13]. Other complications include right ventricular failure, aortic insufficiency, and infection. Left ventricular assist device thrombosis etiology is multifactorial and thus presents complex and challenging problems in the diagnosis and management of such patients [14]. The conditions associated with LVAD thrombosis are divided into three large groups: (a) pump-related, (b) patient-related, and (c) management-related [14]. Left ventricular assist device thrombosis occurs in 2-13\% of adult patients with a continuous-flow LVAD (axial-flow: 4-13\%, centrifugalflow: $2 \%$ ) [6]. Thrombus may be formed at various sites, i.e. left ventricle, inflow cannula, pump housing, outflow cannula, outflow graft, or the aortic root, thus leading to serious cardiovascular events including thromboembolic stroke, peripheral thromboembolism, LVAD malfunction with reduced systemic flows or life-threatening hemodynamic impairment, cardiogenic shock, and even death [6, 15]. The four clinical signs of LVAD thrombosis recognized are as follows: (a) isolated power elevations, (b) isolated $\mathrm{LDH}$ rise, (c) evidence of hemolysis, and (d) new heart failure symptoms [14]. The multidisciplinary and multi-institutional ISHLT group proposed an algorithm for the diagnosis and management of LVAD thrombosis [13].

Left ventricular assist device patients experience significant baseline activation of endothelial and coagulation systems, further accentuated in the early postoperative period [16]. More importantly, prolonged activation of the endothelial and coagulation systems was also reported, which may indicate activation of the extrinsic (tissue factor) pathway of thrombosis mediated by sustained endothelial dysfunction in these patients [16]. Elevated D-dimer concentrations, as found in our study, may reflect chronic, ongoing activation of the coagulation system [17]. Elevated concentrations of fibrinogen, factor VIII, and VWF might result in a hypercoagulable state resulting in LVAD thrombosis. Elevated factor VIII levels have been associated with an increased risk of thrombosis [18]. Conditions leading to the increase of factor VIII levels can be genetic or acquired. More importantly, we have to keep in mind that factor VIII is an acute-phase protein (malignancy, chronic diseases, infections). Thus, genetic or acquired conditions determining high factor levels might predispose patients to LVAD thrombosis. The VWF has a pivotal role in thrombogenesis, and high plasma levels of VWF have been associated with increased risk of thrombosis [19]. A varied response to the antiplatelet regimen, as demonstrated during the study period, may also predispose to thrombosis, namely white thrombus formation. One study found that ASA doses at or below $81 \mathrm{mg} /$ day were an independent predictor of device thrombosis [20]. Pacholewicz et al. reported that pump thrombosis was preceded by an almost surprising increase in platelet aggregation induced by ASPI and ADP [21]. Thus the authors argue that an increase of platelet reactivity or non-response (or low response) to antiplatelet therapy may, in part, play a role in pump thrombosis. Indeed, elevated expression of platelet membrane receptors, namely CD62P and CD63, have been reported in patients on LVAD [22]. Moreover, highly variable platelet aggregation induced by different agonists was also observed [23]. Left ventricular assist device thrombosis has been reported in non-responders to aspirin [24] and clopidogrel [25].

In addition to thrombosis, bleeding has recently been identified as one of the most common adverse events of LVAD therapy and is the major cause of morbidity [9]. Much of the bleeding risk may be associated with the antithrombotic regimens. Having said that, some authors report that the increased risk of bleeding is higher than would be attributed to antithrombotic therapy [10]. The most commonly reported sources of bleeding are epistaxis, Gl bleeding, bleeding of the mediastinum and thorax, and intracranial hemorrhage. The incidence of bleeding, depending on its definition, varies widely between $10 \%$ and $50 \%$, with no difference in the overall bleeding rates between axial- and pulsatile-flow devices [9]. The prevalence of $\mathrm{Gl}$ and intracranial bleeding is $30 \%$ and $11 \%$ respectively [26]. Consequently, hemorrhagic adverse events are more prevalent than thrombo-embolic events. The mechanisms underlying bleeding in LVAD patients are complex and not yet fully understood, and include colonic dysplasia, concomitant use of anticoagulant and antiplatelet agents, and the presence of acquired bleeding diathesis (acquired von Willebrand syndrome type $2 \mathrm{~A}$ resulting from the deficiency of high-molecular-weight vWF multimers). As such, high-molecular-weight vWF multimers declined in patients with $\operatorname{LVAD}[27,28]$, but returned to normal in 6 patients after heart transplantation [29]. However, in the present study we measured only vWF antigen, which is generally within the normal range or elevated and cannot be used in the confirmation or exclusion of acquired von Willebrand syndrome type $2 \mathrm{~A}$. The sensitivity of various laboratory tests for VWS2A in patients with bleeding GI dysplasia is as follows: gel electrophoresis (quantification of HMWM) > PFA-100 closure time $>$ vWF:RCo $>$ bleeding time $>$ vWF:Ag $[15,30]$.

The coagulation system response to LVAD presence varies greatly between patients. It would seem that LVAD recipients achieve a new equilibrium between prothrombotic and prohemorrhagic states [31]. More importantly, there is a fine and complex balance in the management of such patients of overcoagulation and undercoagulation.

Management protocols for LVAD are usually institutiondependent, and unfortunately, there is a large variability in clinician-related factors. We have to keep in mind that the "one size fits all" approach is impractical and ineffective. Therefore, individually tailored antithrombotic therapy protocols must exist in centers managing LVAD recipients.

It has to be noted that our study has some limitations. We did not assess the dysfunction of VWF (in particular the 
deficit of high molecular weight multimers of vWF assessed in gel electrophoresis). Moreover, we did not use thromboelastographic (TEG) monitoring, which could have provided additional information, as TEG is uniquely capable of showing the combined interaction of coagulation factors, platelet content, and platelet function in the process of clot production in whole blood.

\section{Conclusions}

Patients with end-stage heart failure on LVAD therapy demonstrate significant time-dependant changes in hemostasis parameters that could be attributable to the risk of developing both thrombotic and bleeding events. However, further studies are needed to determine whether these changes could serve as biomarkers of such events.

\section{Funding}

The creation of the paper was supported by a grant funded by the Medical University of Silesia (No. KNW-1$163 / \mathrm{N} / 4 / 0$ )

\section{Disclosure}

Authors report no conflict of interest.

\section{References}

1. Ponikowski P, Voors AA, Anker SD, Bueno H, Cleland JG, Coats AJ, Falk V, González-Juanatey JR, Harjola VP, Jankowska EA, Jessup M, Linde C, Nihoyannopoulos P, Parissis JT, Pieske B, Riley JP, Rosano GM, Ruilope LM, Ruschitzka F, Rutten FH, van der Meer P; Authors/Task Force Members. 2016 ESC Guidelines for the diagnosis and treatment of acute and chronic heart failure: The Task Force for the diagnosis and treatment of acute and chronic heart failure of the European Society of Cardiology (ESC). Developed with the special contribution of the Heart Failure Association (HFA) of the ESC. Eur Heart J 2016; 37: 2129-2200.

2. Yusen RD, Edwards LB, Kucheryavaya AY, Benden C, Dipchand Al, Goldfarb SB, Levvey BJ, Lund LH, Meiser B, Rossano JW, Stehlik J. The Registry of the International Society for Heart and Lung Transplantation: Thirty-second Official Adult Lung and Heart-Lung Transplantation Report--2015; Focus Theme: Early Graft Failure. J Heart Lung Transplant 2015; 34: 1264-1277.

3. Susen S, Rauch A, Van Belle E, Vincentelli A, Lenting PJ. Circulatory support devices: fundamental aspects and clinical management of bleeding and thrombosis. J Thromb Haemost 2015; 13: 1757-1767.

4. Szygula-Jurkiewicz B, Szczurek W, Suliga K, Rempega G, Rajwa P. Mechanical circulatory support in heart failure. Kardiochir Torakochir Pol 2016; 13: 130-134.

5. Rosenthal JL, Starling RC. Coagulopathy in mechanical circulatory support: a fine balance. Curr Cardiol Rep 2015; 17: 114.

6. Bartoli CR, Ailawadi G, Kern JA. Diagnosis, nonsurgical management, and prevention of LVAD thrombosis. J Card Surg 2014; 29: 83-94.

7. Stulak JM, Cowger J, Haft JW, Romano MA, Aaronson KD, Pagani FD. Device exchange after primary left ventricular assist device implantation: indications and outcomes. Ann Thorac Surg 2013; 95: 1262-1267; discussion 1267-1268.

8. Barbieri A, Bertelli L, Sangiorgi GM. Novel application of Angiojet rheolytic thrombectomy for massive thrombosis of the native aortic valve and Jarvick 2000 ventricular assist device in a patient with end-stage heart failure. Catheter Cardiovasc Interv 2011; 78: 958-961.

9. Suarez J, Patel CB, Felker GM, Becker R, Hernandez AF, Rogers JG. Mechanisms of bleeding and approach to patients with axial-flow left ventricular assist devices. Circ Heart Fail 2011; 4: 779-784.

10. Crow S, John R, Boyle A, Shumway S, Liao K, Colvin-Adams M, Toninato C, Missov E, Pritzker M, Martin C, Garry D, Thomas W, Joyce L. Gastrointestinal bleeding rates in recipients of nonpulsatile and pulsatile left ventricular assist devices. J Thorac Cardiovasc Surg 2009; 137: 208-215.
11. Gorlinger K, Bergmann L, Dirkmann D. Coagulation management in patients undergoing mechanical circulatory support. Best Pract Res Clin Anaesthesiol 2012; 26: 179-198.

12. Eckman PM, John R. Bleeding and thrombosis in patients with continuousflow ventricular assist devices. Circulation 2012; 125: 3038-3047.

13. Goldstein DJ, John R, Salerno C, Silvestry S, Moazami N, Horstmanshof D, Adamson R, Boyle A, Zucker M, Rogers J, Russell S, Long J, Pagani F, Jorde U. Algorithm for the diagnosis and management of suspected pump thrombus. J Heart Lung Transplant 2013; 32: 667-670.

14. Blitz A. Pump thrombosis - A riddle wrapped in a mystery inside an enigma. Ann Cardiothorac Surg 2014; 3: 450-471.

15. Hudzik B, Kaczmarski J, Pacholewicz J, Zakliczynski M, Gasior M, Zembala M. Von Willebrand factor in patients on mechanical circulatory support a double-edged sword between bleeding and thrombosis. Kardiochir Torakochir Pol 2015; 12: 233-237.

16. John R, Panch S, Hrabe J, Wei P, Solovey A, Joyce L, Hebbel R. Activation of endothelial and coagulation systems in left ventricular assist device recipients. Ann Thorac Surg 2009; 88: 1171-1179.

17. John R, Lee $\mathrm{S}$. The biological basis of thrombosis and bleeding in patients with ventricular assist devices. J Cardiovasc Transl Res 2009; 2: 63-70.

18. Jenkins PV, Rawley O, Smith OP, O'Donnell JS. Elevated factor VIII levels and risk of venous thrombosis. Br J Haematol 2012; 157: 653-663.

19. Franchini M, Lippi G. Von Willebrand factor and thrombosis. Ann Hematol 2006; 85: 415-423.

20. Najjar SS, Slaughter MS, Pagani FD, Starling RC, McGee EC, Eckman P, Tatooles AJ, Moazami N, Kormos RL, Hathaway DR, Najarian KB, Bhat G, Aaronson KD, Boyce SW; HVAD Bridge to Transplant ADVANCE Trial Investigators. An analysis of pump thrombus events in patients in the HeartWare ADVANCE bridge to transplant and continued access protocol trial. J Heart Lung Transplant 2014; 33: 23-34.

21. Pacholewicz J, Kuliczkowski W, Kaczmarski J, Zakliczyński M, Garbacz M, Zembala M, Serebruany V. Activated hemostatic biomarkers in patients with implanted left ventricle assist devices: are heparin and/or clopidogrel justified? Cardiology 2015; 131: 172-176.

22. Matsubayashi H, Fastenau DR, McIntyre JA. Changes in platelet activation associated with left ventricular assist system placement. J Heart Lung Transplant 2000; 19: 462-468.

23. Etz C, Welp H, Rothenburger M, Tjan TD, Wenzelburger F, Schmidt C, Scheld HH, Schmid C. Analysis of platelet function during left ventricular support with the Incor and Excor system. Heart Surg Forum 2004; 7: E423-E427.

24. Dalen M, Sartipy U, Corbascio M, Lund LH, Grinnemo KH. HeartWare left ventricular assist device thrombosis in aspirin non-responder. Asian Cardiovasc Thorac Ann 2014; 22: 203-204.

25. Popov AF, Hosseini MT, Hards R, Amrani M, Bahrami T, Simon AR. Left ventricular assist device thrombosis due to clopidogrel resistance. Asian Cardiovasc Thorac Ann 2012; 20: 489.

26. Slaughter MS, Rogers JG, Milano CA, Russell SD, Conte JV, Feldman D, Sun B, Tatooles AJ, Delgado RM 3rd, Long JW, Wozniak TC, Ghumman W, Farrar DJ, Frazier OH; HeartMate II Investigators. Advanced heart failure treated with continuous-flow left ventricular assist device. N Engl J Med 2009; 361: 2241-2251.

27. Klovaite J, Gustafsson F, Mortensen SA, Sander K, Nielsen LB. Severely impaired von Willebrand factor-dependent platelet aggregation in patients with a continuous-flow left ventricular assist device (HeartMate II). J Am Coll Cardiol 2009; 53: 2162-2167.

28. Uriel N, Pak SW, Jorde UP, Jude B, Susen S, Vincentelli A, Ennezat PV, Cappleman S, Naka Y, Mancini D. Acquired von Willebrand syndrome after continuous-flow mechanical device support contributes to a high prevalence of bleeding during long-term support and at the time of transplantation. J Am Coll Cardiol 2010; 56: 1207-1213.

29. Geisen U, Heilmann C, Beyersdorf F, Benk C, Berchtold-Herz M, Schlensak C, Budde $\mathrm{U}$, Zieger B. Non-surgical bleeding in patients with ventricular assist devices could be explained by acquired von Willebrand disease. Eur J Cardiothorac Surg 2008; 33: 679-684.

30. Warkentin TE, Moore JC, Anand SS, Lonn EM, Morgan DG. Gastrointestinal bleeding, angiodysplasia, cardiovascular disease, and acquired von Willebrand syndrome. Transfus Med Rev 2003; 17: 272-286.

31. Tchantchaleishvili V, Sagebin F, Ross RE, Hallinan W, Schwarz KQ, Massey HT. Evaluation and treatment of pump thrombosis and hemolysis. Ann Cardiothorac Surg 2014; 3: 490-495. 